\title{
Risk Behavior Versus Self-Care in Adolescents
}

\author{
Františka Petriková \\ Vladimír Lichner \\ Eva Žiaková
}

\begin{abstract}
The presented paper is focuses on the issue of self-care as a possible predictor of risky behavior in the target population of of adolescents. The first part of the paper is focused on the theoretical basis of risky behavior and then on the basis of self-care. Within risk behavior, the paper discusses the charakteristics of this concept, the factors influencing the risk behavior of adolescents and also the basic forms of risk behavior in the target group. Within self-care, the paper focuses on defining the basis characteristics of the concept and subsequently on the self-care factors proposed for adolescents and on the self-care as a preventive factor. The second part of the paper focuses on the results of research in the researched issues. The research is focused on demonstrating the differences and relationships between the examined variables.
\end{abstract}

Keywords: Self-Care, Risk Behavior, Adolescents, the Forms of Risk Behavior, the Factors of Self-Care

\section{Introduction}

The concepts of self-care and risk behaviour are interconnected. During adolescence, risk behaviour is more frequent, but self-care can reduce it. The first part of this paper presents a model of risk behaviour with the focus on adolescence. Subsequently, the theoretical background for self-care in adolescence and the components of self-care are explained. Besides general self-care, specific self-care components focused on school and family are also relevant for adolescents. This part of the paper deals with self-care as a risk behaviour prevention factor. The second part of the paper is empirical and presents the research results. A correlation between the variables was discovered, which is important. Statistically significant gender differences were also discovered for both self-care and risk behaviour.

\section{The model of risk behaviour}

Identification of risk behaviour as a phenomenon was preceded by a broad range of social and cultural changes. These changes include weakening of the socialising and individual functions of family, urbanisation, impersonal relationships, constant changes in the labour market, and also digitalisation. In relation to these changes, early childhood is no longer the highest-risk stage of life - adolescence is (Kagan, 1991, in: Čerešník, 2019). Adolescents are the highestrisk group because they are undergoing personality changes. Under the social influence of their peers and broader social environment, they change their behaviour and experiment with a variety of addictive substances, or identify with different subcultures (Lichner, Šlosár, 2017). During adolescence, risk behaviour increases, which affects their physical or mental health 
(Nielsen, Sobotková et al., 2014). Through risk behaviour, adolescents try to reduce the undesired and achieve the desired, leave the common and familiar, and separate from their family, i.e. they search for ways to saturate their unfulfilled needs and seek people who can provide them with social comfort (Čerešník, 2019). Individual forms of risk behaviour usually involve a compromise between a short-term gain and potential long-term negative consequences (Orosová, Gajdošová, Madarasová-Gecková, van Dijk, 2007).

Risk behaviour is determined by the ratio between risk and protective factors. This ratio further determines whether occasional experimentation turns into a risk behaviour syndrome in adolescence. The protective factors can effectively balance out the influence of the risk factors. It can also be assumed that thanks to the protective factors, problematic behaviour will not develop in adolescents (Jessor, 1991). The function of protective factors is usually understood as their ability to directly influence risk behaviour. The goal of these factors is to affect the consequences of risk behaviour, disrupt the interaction between multiple risk factors, or even prevent the emergence of risk factors in the first place (Orosová, 2007).

There are two basic lines of thinking about risk behaviour. In the broader sense, risk behaviour is defined as a social construct comprising a variety of behaviours, which pose health, social, and psychological risks to an individual as well as their social environment (Siruček, Siručková, Macek, 2007). In the narrower sense, such behaviour puts the adolescent's identity, health, or life at risk; complicates or prevents healthy, standard separation from parents; and damages the adolescent's future self-esteem and self-worth (Kocourková, Koutek, 2003).

The causes and development of risk behaviour are multifactorial, i.e. certain interaction of biological, social, and mental factors comes into play (Vágnerová, 2004). The emergence of risk behaviour in adolescents also depends on individual and environmental factors (places where the adolescent spends their free time; place where they are growing up; school environment; peer environment) (Punová, 2012; Kipping et al., 2012).

Risk behaviour can be divided into the following five basic categories:

intellectual/mental: related to manifesting knowledge and potential in front of the others, which may put the person at risk of alienation from their peers

social: includes changes in the social or peer group; socialisation is very important during adolescence as the person is learning how to join a collective

emotional: manifesting fear; other members of the social group learn about the adolescent's vulnerability

physical: taking risk to achieve a success and win a position among the peers

spiritual: a change in religious beliefs may lead to developing risky spiritual habits (Neihart, 1999)

The aforementioned categories of risk behaviour may have vast consequences for the emergence and increase of socially pathological phenomena in different risk groups. However, it is generally assumed that such increase can be eliminated by means of properly targeted preventive programmes at primary and high schools.

Specialised literature specifies three main areas of risk behaviour symptoms. The first area relates to addictive substance abuse (the adolescent is motivated to overuse addictive substances in order to be included in the peer group); The second area includes psychosocial 
manifestations (antisocial behaviour often referred to as behavioural disorders) and the third area affects reproductive behaviour (premature sexual life, promiscuity, risky sexual behaviour) (Jessor, Turbin, 2010; Čerešník, Gatial, 2014; Novotný, Okrajek, 2012). The research presented in this paper focuses on the aforementioned risk behaviour areas. Specifically, they are addressed in the questionnaire of risk behaviour, which was used to collect data on the individual forms of risk behaviour in adolescents.

The main and most frequent forms of risk behaviour in adolescents include delinquency and criminal behaviour, addictive substance abuse, bullying, hostility, risky sexual behaviour, eating disorders, behavioural disorders, self-harm and suicidal actions (Dolejš, 2010; Miovský et al., 2012; Macek, 2003).

\section{The model of self-care in adolescents}

Self-care is perceived as a form of protection from undesirable environmental phenomena. The interest in a comprehensive concept of self-care as a means to improve one's health and well-being is recurrent. On the other hand, it can also be used to reduce the negative effects of the environment (El-Osta et al., 2019). Specialised literature defines self-care as a set of activities performed on one's own initiative with the aim to self-regulate their functioning and development (Godfrey et al., 2011; Denyes, Orem, Bekel, 2001). However, no complex framework capturing self-care in its complexity is available so far. The fact that the concept still has not been unified may be hampering its further development.

Self-care comprises four main dimensions:

Self-Care Activities represent the dimension focused on "self". It includes activities related to individual self-development. Appropriate intervention improves the individual's overall health and well-being. During adolescence, it is important to focus on activities that will not affect further development negatively.

Self-Care Behaviours focus on activities promoting positive behaviour in individuals. This dimension is individually oriented but can be extended to a community or society through positive interaction and suitable tools. Positive peer influence during adolescence can reduce risk behaviour at this stage of development.

The Self-Care Context as a dimension focuses on the individual's overall reliance on resources. Based on the level of reliance, intervention is targeted at the healthcare system in the country or at supporting the individual.

The Self-Care Environment is nation-wide. It depends upon the prevailing cultural and social attitudes. This dimension relates to public health in the whole country (El-Osta et al., 2019).

\subsection{The components of self-care in adolescents}

The components of self-care in adolescents focus on the specificities of adolescence as a developmental period. The components, which will be specified further on, focus on three areas: psychological, physical, and social, but they also have to do with the environments in which the adolescent lives (school, family, peers). Specialised literature distinguishes six main self-care components in adolescents.

School self-care strategies - school is considered a space for education, which has a major effect on the individual's formation. The whole system is determined by social relationships (Lee, Bryk, Smith, 1992). The school is a space in which students develop mutual relationships 
and are subject to social influence; they also form relationships with teachers and authority in general (Obdržálek, 1999; Szijjártóová, Malá, 2008). Besides education, school also fulfils the need for socialisation, therefore, it is perceived as a social institution (Havlík, Kot'a, 2002). The school environment creates and maintains complex networks of social relationships and significantly affects thinking, attitudes, and feelings. It also plays a role in the formation of culture, habits, and rituals (Juhásová, Debnáriková, 2016). Inchley et al. (2016) and Zelina (2000) emphasize that good education provides great prevention against behavioural issues, personality disorders, or loss of the meaning of life. External support plays an important role in learning how to perform self-care. Parental support is the most necessary when school-aged children are learning self-care (Kello, Martikainen, Eriksson, 2011).

Social climate in the school environment - the school climate affects the quality of interpersonal interaction, which indicates the level of performance, cooperation, and competition. The overall climate is created by the relationships between teachers, students, school management, and other upbringing factors involved in the process. Social climate can be divided into social climate in the school environment and classroom social climate. Social climate in the school environment is considered an organisational element as it is affected by the school as an organisation. A school that creates healthy environment provides an accepting, supportive, and beneficial climate and builds a quality reputation (Szijjártóová, Malá, 2008). Classroom social climate is created by the students themselves; their relationships, mutual support and cooperation are important.

Deliberate problem-solving strategies - this component focuses on the individual's ability to deal with problems related to school, family, or their own personality. Positive problemsolving strategies enhance learning and school performance, increase creativity and improve understanding of complex situations (Stuchlíková, 2002). In general, maladaptive and adaptive strategies exist. Maladaptive strategies use ineffective procedures and result in failure, which further decreases the individual's well-being. Adaptive ones are effective and play a specific role in creating psychological well-being, i.e. they are positive determinants.

Universal self-care - refers to day-to-day activities in an adolescent's life. This component involves the individual's level of independence in the self-care activity. In this case, universality refers to prevention of negative behaviour, balanced periods of activity and relaxation, and self-support for proper functioning (Hartweg, 1991). According to Jaarsma et al. (2003), self-care can be universal and it can be invited by health problems or the developmental context.

Adolescents' free time - the ways in which adolescents spend their free time change along with society itself. Over time, the responsibility for the child's free time and the way it is used is transferred from parents to other people (siblings, friends, teachers, tutors...). The individual's scope of interest and activities is broadest during adolescence in comparison with other stages of life (Sak, 2000). Adolescents' free-time activities can be divided as follows: cultural, extroverted, manual, sport (Kraus, 2006).

Family-oriented personal component - during adolescence, individuals start focusing on themselves and their relationship with people close in terms of age or interests. It is a period of emancipation from their own parents (Macek, Lacinová, 2006; Vágnerová, 2012; Macek, Štefánková, 2006). In family, efforts to gain more equality can be observed while among peers, 
the adolescent tries to find their place (Macek, 2003). The changing quality of interpersonal relationships during adolescence is one of its basic psychosocial characteristics.

Factors of self-care are determined by the characteristics of an adolescent, self-care as such, but also support provided by parents, school environment, and peers (Kelo, Martikainen \& Eriksson, 2011). At the time, the adolescent is in the process of creating their own self-image and self-assessment, i.e. these attributes are not stabilised yet, and the person is also learning self-efficacy (Macek, 2008) - all these aspects affect the factors of self-care.

\section{Self-care as a preventive factor}

Self-care can also be considered a preventive factor as it reduces risk behaviour symptoms. If self-care is lacking, the probability that risk behaviour symptoms will occur increases. Selfcare as a factor preventing negative phenomena in behaviour works in the following way: early positive intervention in the form of preventive programmes, activities, and methods influences the individual and may reduce or even eliminate their risk behaviour.

Literature distinguishes three basic forms of prevention. They involve activities focused on self-care, which provide proper help, support, and company (Orosová, 2003; Schavel, Číšecký, Oláh, 2010).

Primary (universal) prevention as the first form should be provided at schools before undesirable behaviour occurs. Primary prevention takes the form of workshops, preventive programmes, and lectures given by experts (Emmerová, 2003).

On the other hand, secondary (selective) prevention focuses on tackling a specific, already existing problem (Božeková, 2014; Kulifaj, 2017). It provides early intervention and identifies individual as well as group problems. Secondary intervention is focused specifically on the individual at risk. The goal of this form of prevention is to stop a disorder from developing further (Svetlíková, 2018).

Tertiary prevention aims to reduce risks resulting from socially pathological phenomena and improve individuals' lives. It comes into play if primary and secondary prevention fail. Tertiary prevention can take the form of preventive programmes focused on reducing and removing the existing symptoms of risk behaviour.

The main goal of prevention is to deliberately promote non-risk and socially accepted forms of behaviour instead of the risk ones. Self-care in prevention should influence all areas of individual development as well as the environment in which the adolescent lives. The goal of prevention is not only to temporarily avoid certain negative environmental factors, but also apply appropriate methods and perform activities promoting desirable behaviour. The legislative framework of social prevention specifies it as an inseparable part of social work (Galáš, 2006). Lack of self-care may trigger the development of socially pathological phenomena in adolescents. To sum up, lack of self-care is a potential risk factor.

\section{Research}

Self-care is a rather new concept when it comes to the adolescent population. In a broader sense, this study investigates the increased risk behaviour during adolescence. Specifically, it focuses on the relationship between self-care and reducing risk behaviour in adolescents as a target group, and in this part, the research results will be presented. 


\subsection{Methods}

SCA - questionnaire about self-care in adolescents (Lichner, Petriková, Žiaková, 2020). The questionnaire was designed specifically for adolescents as the target group. The questionnaire consists of 35 items and the participant is asked to express their agreement or disagreement on a 6 -point Likert scale; $1=$ strongly disagree to $6=$ strongly agree with the given statement. The 6-factor research instrument comprises the following factors: SOS school strategies, social climate in the school environment, deliberate coping strategies, adolescents' free time, and their family. The reliability (internal consistency) of the research instrument was $\alpha=0.876$. Internal consistency of the individual factors ranged from $=$.

RBQ - Risk behaviour questionnaire (Lovašová, 2019). The instrument focuses on risk behaviour in adolescents. The questionnaire consists of 28 items and the participant is supposed to express their agreement or disagreement on a 5-point Likert scale; $1=$ strongly agree to $5=$ strongly disagree. Again, the questionnaire investigates six factors: xenophobic and aggressive behaviour, virtual reality, risk health habits, internet addiction, self-harm, risk sexual behaviour. The respondent is also supposed to complete "During the last year, the following happened to me...". This instrument focuses on delinquency-related issues during adolescence, sexual risk behaviour, problems related to information technologies, eating disorders, and xenophobia. Internal consistency of the research instrument was $\alpha=0.863$. Internal consistency of the individual factors ranged from $\alpha=0.653$ to 0.809 .

The questionnaire also collected sociodemographic data (age, gender, place of living, information on relationships with peers and family).

\subsection{Research file}

The research file consisted of 364 respondents (boys=112; girls=268; 5 respondents did not specify their gender). The mean age was 17 (4 respondents did not specify their age). $(\mathrm{SD}=0.818 ; \mathrm{Min}=14 ; \mathrm{Max}=19)$. The selection can be described as stratified random data collection. Selection in the classroom was not random as all the students present at the time participated as a compact group. The research instruments were administered personally during classes. The research sample consisted of high school students in the Slovak Republic. Educational background was divided as follows, 70 participants had studied at a medical high school; 41 at a business academy, 82 at a vocational high school; and 192 had studied at grammar schools.

\subsection{Organisation of the research}

The research was performed in January 2020. Stratified random selection was used (by drawing lots). Students from several type of high schools across Slovakia were invited to participate in the research. Specifically grammar schools, vocational high schools, business academies, and medical high schools. The second and third year students were addressed. The research was performed in the following municipalities: Trnava, Prievidza, Nitra, Rakovice, Banská Bystrica, Trenčianske Teplice, Žilina, Martin. The questionnaire was administered in person during the classes and the students had one whole lesson to complete it.

\subsection{Research results}

In this part of the paper, the selected results of the research performed will be presented. It focused on high school students in the Western part of Slovakia. 
The research goal was to investigate the relationship between self-care and risk behaviour in adolescents.

Tables 1 and 2 show the internal consistency of the research instruments; the highest value was measured in the "school self-care strategies" component in the questionnaire about selfcare in adolescents. The factor with the highest internal consistency in the RBQ questionnaire of risk behaviour in adolescents was the one focused on risk health habits.

Fig. 1 Internal consistency of the questionnaire of self-care in adolescents

\begin{tabular}{c|c|c|c|c|c|c}
$\begin{array}{c}\text { Self-care } \\
\text { components }\end{array}$ & $\begin{array}{c}\text { School self- } \\
\text { care } \\
\text { strategies }\end{array}$ & $\begin{array}{c}\text { Social } \\
\text { climate in } \\
\text { the school } \\
\text { environment }\end{array}$ & $\begin{array}{c}\text { Deliberate } \\
\text { coping } \\
\text { strategies }\end{array}$ & $\begin{array}{c}\text { Universal } \\
\text { self-care }\end{array}$ & $\begin{array}{c}\text { Adolescents' } \\
\text { free time }\end{array}$ & Family \\
\hline$\alpha$ & 0.796 & 0.734 & 0.720 & 0.744 & 0.628 & 0.763
\end{tabular}

Fig. 2 Internal consistency of the questionnaire on risk behaviour

\begin{tabular}{c|c|c|c|c|c|c}
$\begin{array}{c}\text { Risk } \\
\text { behaviour } \\
\text { components }\end{array}$ & $\begin{array}{c}\text { Xenophobic } \\
\text { and } \\
\text { aggressive } \\
\text { behaviour }\end{array}$ & $\begin{array}{c}\text { Virtual } \\
\text { reality }\end{array}$ & $\begin{array}{c}\text { Risk } \\
\text { health } \\
\text { habits }\end{array}$ & $\begin{array}{c}\text { Internet } \\
\text { Addiction }\end{array}$ & Self-harm & $\begin{array}{c}\text { Risk } \\
\text { sexual } \\
\text { behaviour }\end{array}$ \\
\hline$\alpha$ & 0.653 & 0.674 & 0.809 & 0.706 & 0.688 & 0.689
\end{tabular}

Fig. 3 Age distribution of research sample

\begin{tabular}{c|c|c} 
AGE & $\mathrm{f}$ & $\%$ \\
\hline 14 & 1 & 0.3 \\
\hline 15 & 9 & 2.5 \\
\hline 16 & 94 & 25.8 \\
\hline 17 & 170 & 46.7 \\
\hline 18 & 82 & 22.5 \\
\hline 19 & 5 & 1.4 \\
\hline Missing & 3 & 0.8 \\
\hline TOTAL & 364 & 100
\end{tabular}

As can be seen in Table 3, the primary research sample consisted of adolescents studying at high schools. The target group was selected deliberately based on its developmental specificities and increased tendency to risk behaviour. The respondents' average age was 17 years.

The focus was on the relationship between overall self-care and overall risk behaviour in adolescents. The Spearman's rank correlation coefficient (non-parametric statistics) was used for statistical processing.

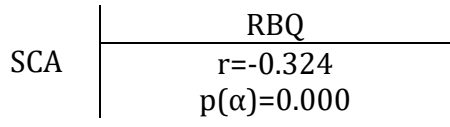


$\mathrm{N}=364$

Fig. 4 The correlation between self-care and risk behaviour

*** $\mathrm{p}<0.001$

Table 4 shows a statistically significant correlation between the concept of self-care and the concept of risk behaviour $p(\alpha)=0.000$. The relationship between the investigated variables is medium strong but negative. Negative correlation indicates that as one variable increases, the other decreases. It means that increased self-care reduces risk behaviour in adolescents.

Subsequently, gender differences were investigated in all self-care components. The differences can be seen in Table 5. Gender differences in self-care components were identified using the Mann-Whitney $U$ test. Based on these results, it can be stated that statistically significant differences were found in two self-care components. Specifically, deliberate problem-solving strategies and adolescents' free time. Other self-care components showed certain gender differences as well, however, none of them statistically significant.

Fig. 5 Gender differences in the self-care components

\begin{tabular}{c|c|c|c|c|c|c}
$\begin{array}{c}\text { SCA } \\
\text { component }\end{array}$ & gender & $\mathrm{n}$ & $\mathrm{X}$ & $\operatorname{Med}(\mathrm{x})$ & $\mathrm{Z}$ & $\mathrm{p}(\alpha)$ \\
\hline \multirow{3}{*}{ SCA1 } & Males & 102 & 3.62 & 3.71 & -0.035 & 0.972 \\
\cline { 2 - 5 } SCA2 & Females & 258 & 3.62 & 3.71 & & \\
\cline { 2 - 5 } & Males & 102 & 4.33 & 4.57 & -1.063 & 0.288 \\
\cline { 2 - 5 } SCA3 & Memales & 258 & 4.23 & 4.42 & & \\
\cline { 2 - 5 } & Females & 102 & 4.87 & 5 & -3.179 & 0.001 \\
\hline \multirow{3}{*}{ SCA4 } & Males & 102 & 5.20 & 5.43 & -1.676 & 0.094 \\
\cline { 2 - 5 } SCA5 & Females & 258 & 5.3 & 5.50 & & \multirow{2}{*}{0.063} \\
\cline { 2 - 5 } & Males & 102 & 3.54 & 3.60 & -1.862 & \\
\hline \multirow{2}{*}{ SCA6 } & Memales & 258 & 3.30 & 3.40 & & 0.818 \\
\cline { 2 - 5 } & Memales & 102 & 4.47 & 4.66 & -0.230 &
\end{tabular}

$* * * \mathrm{p}<0.001$

SCA1 - school self-care strategies SCA2 - social climate in the school environment SCA3 deliberate coping strategies SCA4 - universal self-care SCA5 - adolescents' free time SCA6 family

The following table shows gender differences in adolescent risk behaviour. Statistically significant differences in components focused on xenophobic and aggressive behaviour, risk health habits, and self-harm were confirmed. Some differences were found in other components as well, but none of them statistically significant.

Fig. 6 Gender differences in the risk behaviour components

\begin{tabular}{c|c|c|c|c|c|c}
$\begin{array}{c}\text { RBQ } \\
\text { component }\end{array}$ & gender & $\mathrm{n}$ & $\mathrm{X}$ & $\operatorname{Med}(\mathrm{x})$ & $\mathrm{Z}$ & $\mathrm{p}(\alpha)$ \\
\cline { 1 - 5 } $\mathrm{RSI1}$ & Males & 102 & 12.54 & 12 & -3.819 & 0.000 \\
\cline { 2 - 5 } & Females & 258 & 10.11 & 9.2 & & \\
\hline \multirow{2}{*}{ RBQ2 } & Males & 102 & 6.04 & 4.25 & -1.114 & 0.265 \\
\cline { 2 - 5 } & Females & 258 & 5.74 & 3.25 & &
\end{tabular}




\begin{tabular}{c|c|c|c|c|c|c}
\multirow{2}{*}{ RBQ3 } & Males & 102 & 14.11 & 12 & \multirow{2}{*}{-2.474} & 0.013 \\
\cline { 2 - 5 } & Females & 258 & 16.26 & 16 & & \\
\hline \multirow{3}{*}{ RBQ4 } & Males & 102 & 22.81 & 23.58 & -1.108 & 0.268 \\
\cline { 2 - 5 } RBQ5 & Females & 258 & 23.8 & 25 & & \\
\cline { 2 - 5 } & Males & 102 & 9.75 & 9.25 & -4.081 & 0.000 \\
\cline { 2 - 5 } $\begin{array}{c}\text { RBQ6 } \\
*\end{array}$ & Males & 258 & 12.31 & 12.25 & & \\
\cline { 2 - 5 }$* 0.001$ & Females & 258 & 6.54 & 3.25 & -1.413 & 0.158 \\
\multirow{2}{*}{$\mathrm{p}<0.071$} & & & & \\
\end{tabular}

RBQ1 - xenophobic and aggressive behaviour RBQ2 - virtual reality RBQ3 - risk health habits RBQ4 - Internet addiction RBQ5 - self-harm RBQ6 - risk sexual behaviour

The investigation proved gender differences in self-care and risk behaviour within the target group.

\section{Discussion and conclusion}

In this part of the paper, the results will be compared with other research focused on similar subject matter. Kirk and Pryjmachuk (2019) researched self-care in adolescents with persistent mental problems. Their research sample consisted of adolescents under 18 years and their main research method was the meta-analysis of research findings. The study showed that self-care improves mental health in adolescents and reduces the consequences of mental disorders. The research also showed that self-care reduces the costs of health care in mentally ill adolescents. Masoumi and Shahhosseini (2019) performed a similar study focused on challenges related to self-care faced by adolescents. Their summarising study analysed a database of previous research. They found that self-care in adolescents differs based on age, gender, and other demographic factors. The main finding was that the expert working with adolescents must be properly acquainted with universal self-care. Besides other factors, the research presented here focused on the gender differences in the individual self-care components. A statistically significant gender difference was confirmed in the component focused on adolescents' psychological attributes (SCA3). Other components showed certain differences, but none of them statistically significant. The findings confirmed that to reduce the probability of risk behaviour, it is necessary for adolescents to perform self-care activities.

Pašková, Stehlíková, Valihorová (2018) performed a study of risk behaviour in early school aged children from the teachers' perspective. The research sample consisted of primary school pupils $(\mathrm{N}=316)$ and 20 teachers at the first stage of primary school. The "Risk behaviour in pupils" scale (Mezera et al., 2000) was used to measure risk behaviour and the authors also measured the gender differences in the individual forms of risk behaviour using the MannWhitney U test. Results showed significant gender differences in almost all forms of risk behaviour (asocial, antisocial, impulsive, maladaptive, negativistic behaviour). They used the same RBQ questionnaire of risk behaviour (Lovašová, 2019) as this study. The research also confirmed gender differences in the individual areas of risk behaviour in adolescents (xenophobic and aggressive behaviour, virtual reality, risk health habits, Internet addiction, self-harm, risky sexual behaviour). Interestingly, our research revealed a higher rate of risk behaviour in girls than in boys. On the contrary, Pašková, Stehlíková and Valihorová found a higher rate in boys. The discrepancy may result from age differences between the research samples in these two studies. 
Selecká, Václaviková, Blatný, and Hrdlička (2017) focused on the typology of antisocial behaviour in adolescents. They used data from the SAHA project and investigated the gender differences in the given type of behaviour. Their results showed that boys and girls differ significantly in almost all aspects of antisocial behaviour and its symptoms (smoking, alcohol, other drugs, sexual activity). The cluster of problem-free individuals in their research file is larger among girls. Again, in our research sample, girls showed a higher rate of risk behaviour than boys.

The presented paper aimed to define self-care in adolescents as a target group. The importance of self-care to reduce risk was confirmed in the research sample. It can be assumed that self-care has a positive effect and reduces risk behaviour symptoms. Based on the presented theoretical and empirical findings, it can be stated that the area of self-care needs to be developed. Its potential could be used positively for preventive and intervention programmes as well as in new methods of working with adolescents as a target group.

\section{References}

[1] Božeková, A. 2014. Sociálny kapitál ako prevencia negatívnej agresivity adolescentov. Ostium, vol. 10, no. 4, pp. 1-11.

[2] Čerešník, M., Gatial, V. 2014. Rizikové správanie a vybrané osobnostné premenné dospievajúcich v systéme nižšieho sekundárneho vzdelávania. Nitra: UKF.

[3] Čerešník, M. 2019. Rizikové správanie, blízke vzt’ahy a sebaregulácia dospievajúcich v systéme nižšieho sekundárneho vzdelávania. SPU Nitra.

[4] Denyes M. J., Orem, D., Bekel, G. 2001. Self-care: a foundational science. Nurs Sci Q. vol. 14, no. 1, pp. 48-54.

[5] Dolejš, M. 2010. Efektívna včasná diagnostika rizikového chování u adolescentů. Olomouc: UP Olomouc.

[6] El-Osta et al. 2019. The self-care matrix: A unifying framework for self-care. SelfCare, vol. 10, no. 3 , pp. 38-56.

[7] Emmerová, I. 2003. Primárna prevencia a programy prevencie drogových závislostí v podmienkach ZŠ v Slovenskej republike. Sociální pedagogika - Pedagogická orientace, 4, pp. 73-82.

[8] Galáš, J. 2006. Činnost' Protidrogového fondu a projekty kultúrnych inštitúcií. Kultúra a primárna prevencia závislostí. Národné osvetové centrum.

[9] Godfrey, C. M. et al. 2011. Care of self - care by other - care of other: the meaning of self-care from research, practice, policy, and industry perspective. International Journal of Evidence-Based Healthcare, 9, pp. 3-24.

[10] Jaarsma, T., Strömberg, A., Martensson, J., Dracup, K. 2003. Development and testing of the European Heart Failure Self-Care Behaviour Scale. The European Journal of Heart Failure, 5, pp. 363-370.

[11] Jessor, R. 1991. Risk behavior in adolescence: a psychosocial framework for understanding and action. Journal of Adolescent Health, vol. 12, no. 8, pp. 597-605.

[12] Jessor, R., Turbin M.S. 2010. Problem Behavior and Psychosocial Developpment: The Role of Psychosocial and Behavior Protection Risk. Journal of Research on Adolescence. Medford: Wiley, vol. 20, no. 3, pp. 707-725.

[13] Juhásová, A., Debnáriková, K. 2016. Školské prostredie ako priestor pre prevenciu delikvencie. Univerzita Komenského v Bratislave.

[14] Havlík, R. Kot’a, J. 2002. Sociologie výchovy a školy. Praha: Portál.

[15] Kagan, J. 1991. Etiologies of Adolescents and risk. Journal of Adolescent Health, vol. 12, no. 5, pp. 591-596. 
[16] Kelo, M., Martikainen, M., Eriksson, E. 2011. Self-care of school-age children with diabetes: an integrative review. Journal of advanced nursing, vol. 67, no. 10, pp. 2096-2108.

[17] Kipping, R. R. et al. 2012. Multiple Risk Behaviour in Adolescence. Journal of Public Health. vol. 34, no. 1, pp. 11-12.

[18] Kirk, S., Pryjmachuk, S. 2019. Self-Care of Young People with Long-Term Physical and Mental Health Conditions. Nursing Children and Young People, vol. 28, no. 7, pp. 20-28.

[19] Kocourkova J., Koutek, J. 2003 Sebevražedné chování. Praha: Portál.

[20] Kraus, B., et al. 2006. Středoškolská mládež a její svět na přelomu století. Brno: Paido.

[21] Kulifaj, P. 2017. Preventívne aktivity. Implementačná agentúra Ministerstva práce sociálnych vecí a rodiny Slovenskej republiky.

[22] Lee, V., E., Bryk, A., S., Smith, J., B. 1992. The Organization of Effective Secondary Schools. Review of Research in Education, 19, pp. 171-267.

[23] Lichner V., Šlosár D. 2017. Problematické používanie internetu u adolescentov v kontextoch teórie a praxe sociálnej práce. Košice: FF UPJŠ.

[24] Macek, P. 2003. Adolescence. Portál.

[25] Macek, P. 2008. Sebesystem, vztah k vlastnimu Ja. In J. Vyrost, I. Slaměnik (Eds.). Sociální psychologie. pp. 181-207. Praha: Grada Publishing. Macek, P., Štefánková, Z. 2006. Vztahy s rodiči a jejich souvislosti s citovou vazbou. Barrister and Principal.

[26] Macek, P. a Lacinová L. 2006. Vztahy v dospívání. Brno: Barrister \& Principal, pp. 41-53.

[27] Masoumi, M., Shahhosseini, Z. 2019. Self-Care Challenges in Adolescents: a Comprehensive Literature Review. International Journal of Adolescent Medicine and Health, vol. 31, no. 2, pp. 1-6.

[28] Mezera, A., et al. 2000. Škála rizikového správania. Bratislava: Psychodiagnostika s.r.o.

[29] Miovský, M. a kol. 2012. Výkladový slovník základních pojmů školské Prevence rizikového chování. Praha: Togga.

[30] Novotný, P. S., Okrajek P. 2012. Vliv vybraných charakteristik rodinného prostředí na rizikové chování 15tiletých adolescent [online]. [cit. 2019-12-12]. In: Psychologie. Elektronický časopis ČMPS. Available at:http://www.vyzkummladez.cz/zprava/1347014675.pdf. ISSN 1802-8853.

[31] Neihart, M. 1999. Systematic risk-taking. In Roeper Review, vol. 21, no. 4, pp. 289-292.

[32] Nielsen Sobotková, V. et al. 2014. Rizikové a antisociální chování v adolescencii. Praha: Grada.

[33] Obdržálek, Z. 1999. Škola, školský systém, ich organizácia a riadenia. Bratislava: Polygrafické stredisko UK.

[34] Orosová, O. 2003. Pomoc - Prevencia - Rovesníci alebo „Preventívne nie nepoškodí: inovatívne metódy v prevencii drogových závislostí v školskej praxi. Košice: Filozofická fakulta Univerzity Pavla Jozefa Šafárika v Košiciach.

[35] Orosová, O., Gajdošová, B., Van Dijk J. P. 2007. Rizikové faktory užívania drog dospievajúcimi. In Československa Psychologie, vol. 51, no. 1, pp. 32-47.

[36] Orosová, O. - Gajdošová, B. - Salonna, F., 2007. Prevencia a prediktívne faktory užívania drog. Košice: Harlequin quality.

[37] Pašková, L., Stehlíková, J., Valihorová, M. 2018. Rizikové správanie žiakov mladšieho školského veku z pohl'adu učitel'ov primárneho vzdelávania. Psychologie a její kontexty, vol. 9, no. 1, pp. 1528.

[38] Punová, M. 2012. Resilience v sociální práci s rizikovou mládeží. In Sociální práce /Sociálna práca, vol. 4, no. 2, pp. 90-104.

[39] Sak, P. 2000. Proměny české mládeže. Praha: Petrklíč.

[40] Selecká, L., Václaviková I., Blatný M., Hrdlička, M. 2017. Typológia antisociálneho správania: Špecifiká prejavov adolescentných chlapcov a dievčat vo vzt'ahu k rizikovému sexuálnemu správaniu. Česká a Slovenská Psychiatrie, vol. 113, no. 6, pp. 258-267.

[41] Schavel, M., Číšecký, F., Oláh, M. 2010. Sociálna prevencia. Vydavatel'stvo: Prohu. 
[42] Stuchlíková, I. 2002. Základy psychologie emocí. Praha: Portál.

[43] Svetlíková, S. 2018. Sociálna prevencia a jej význam. Fakulta sociálnych vied, Katedra sociálnych služieb a poradenstva UCM Trnava.

[44] Szijjártová, K., Malá, D. 2008. Učebný a sociálny proces v triede. Nitra: CCV PF UKF.

[45] Širůček, J., Širůčková, M., Macek, P. 2007. Sociální opora rodičů a vrstevníků a její význam pro rozvoj problémového chování v adolescenci. Československá psychologie, vol. 51, no. 5, pp. 476488.

[46] Vágnerová, M. 2004. Psychopatologie pro pomáhajúcí profese. Praha: Portál.

[47] Vágnerová, M. 2012. Vývojová psychologie. Portál.

The paper is a part of the VVGS-2020-1414 "Tvorba dotazníka pre meranie úrovne starostlivosti o seba u adolescentov/Design of a questionnaire measuring self-care in adolescents" research project. 